\title{
AFRICAN CULTURES AS TOURISM INNOVATIVE CAPABILITY IN SOUTH AFRICAN TOURISM SECTOR: A GAUTENG PROVINCE PERSPECTIVE
}

\author{
Abigail CHIVANDI* \\ University of the Witwatersrand, School of Economics and Business Sciences, Faculty of Commerce, \\ Law and Management, Private Bag 3, WITS, 2050, Johannesburg, South Africa, e-mail: Abigail.Chivandi@wits.ac.za
}

Olorunjuwon SAMUEL

University of the Witwatersrand, Human Resource Management and Management Division, Faculty of Commerce, Law and Management, School of Economic \& Business Sciences, South Africa, Address: Richard Ward,

1 Jan Smuts Ave, Braamfontein, Johannesburg, 2000, South Africa, e-mail: olorunjuwon.samuel@wits.ac.za

Mammo MUCHIE

Tshwane University of Technology Pretoria, Faculty of Management Sciences, Gauteng, South Africa, e-mail: MuchieM@tut.ac.za

\begin{abstract}
Citation: Chivandi, A., Samuel, O., \& Muchie, M., (2020). AFRICAN CULTURES AS TOURISM INNOVATIVE CAPABILITY IN SOUTH AFRICAN TOURISM SECTOR: A GAUTENG PROVINCE PERSPECTIVE. GeoJournal of Tourism and Geosites, 30(2spl), $782-788$. https://doi.org/10.30892/gtg.302spl19-523
\end{abstract}

\begin{abstract}
South Africa, a culturally rainbow nation comprising of various cultures. In tourism industry new trends has emerged whereby tourists consume/ experience indigenous cultures. The study presented a unique historical experience in tourism sector. In order to achieve long-term sustainability, South African tourism industry needs focusing on providing more cultural experiences. The study aimed at understanding impact of South African innovative cultures as an emerging trend in tourism industry and revealed how embracing South African cultures can lead to revisit intentions contributing to tourism business growth. Theoretically, the customer satisfaction theory was employed and enhanced understanding of experience development process in tourism sector. Positivism philosophy was used, Hypotheses were deductively tested SEM, Con firmatory Factor Analysis (CFA) tested reliability and validity, random sampling employed to respondents. AMOS and SPSS 25 obtained CFA, path model determining best model fit. Findings indicated a positive relationship in innovative cultures in the Southern African tourism sector.The results indicated that tourists are more interested in experiencing the cultures of their tourism destinations and this will impact the level of satisfaction that they acquire, as well as their overall revisit intention.
\end{abstract}

Key words: Cultural Experience, Innovative Cultures, revisit intention, Tourism

\section{INTRODUCTION}

The tourism industry plays a colossal role in the Global economy and its emoluments are reaped across the various economic sectors. Because of this immense role that tourism plays, as one of the world's largest economic sectors, jobs are created, exports are driven, and the overall welfare of tourism sector has the potential to grow (David, 2017). Through this, African countries are given the platform to manifest their economic, social, cultural, environmental, and heritage value that the sector can bring they can do wonders (Bryman, 2007). In South Africa the top tourist attractions are, Cape Town and Cape Peninsula, The Winelands, Garden Route, Johannesburg and The Kruger National Park Popular South African Attractions (Pedro, 2008). They offer ample sightseeing experiences, yet a deficit on cultural experience. In previous years South Africa's richness in wildlife parks, scenery and cultural diversity is what gave them a competitive advantage in the tourism industry, this is, however, changing (Burger et al., 2001). This may be problematic for the long-term sustainability of this sector as tourists seek more from their travels. The change of tourists' expectations has given rise to cultural and heritage tourism and is now advocated as an important niche (Merwe, 2016). To remain competitive in the tourism industry, the resources of the country need to be more efficiently and effectively managed to complement human skills and innovations (Burger et al., 2001). Sadly, it can be argued that through colonialism, South Africa lost a significant amount of African representation within the tourism industry.

South Africa is a culturally rich and diverse country, as Desmond Tutu referred to as "The Rainbow Nation" (Chiger, 2016). The original people of the land were the KhoiKhoi and the San. They were later in history joined by the Bantu people, Asian and Europeans during the colonisation of South Africa South African Culture (Chen and Chen, 2010). The Bantu Africans, a term used by the colonist, was made up of northern migraters (Defining the term 'Bantu', 2016). The Bantu migrants are made up of various African cultures which include Zulu, Xhosa, Sotho, Ndebele, Shangaan and Venda South African Culture, (Pedro, 2008) Innovative South African Cultural Music and Dance Entertainment like everything else in South Africa, music and dance too has been influenced by other cultures. Born to African traditions is participation in singing, dancing, clapping and banging of drums (Baker and Crompton, 2000). The Khoi played a guitar like instrument, called a ramkie. With this instrument they made a new form of music by blending Western and Khoi sounds (SAHO, 2016).

The music and dance industry in South Africa has been heavily influenced by the country's political environment which leads to new forms of music like, kwaito, African jazz and mbube (Collison, 2016). South Africa is home to numerous cultures; African, Col oured, Malay, Indian, Chinese and European (South African Culture, Pedro (2008). Despite South Africa's thriving tourism industry and the richness of cultures, it can be argued that the 'rainbow nation' cultures of South Africa are heavily underrepresented in this industry, and thus a cultural experience is not strongly offered to tourist (Babbie and Earl, 2010). This research aimed at showing how embracing African cultures in the tourism entertainment sector can influence the cultural tourism experience of individuals leading to a tourist cultural satisfaction and revisit intention and cultural tourism loyality. Innovative South African Cultural Festivals Entertainment: The largest arts festival takes place in Grahamstown annually (About the National Arts Festival, n.d.), (Munien et al., 2019). It is known as

" Corresponding author 
the National Arts Festival. This festival is open to anyone who would like to showcase their drama, dance, theatre, comedy, music. Cultural Tourism Expected Experience refers to the expectations of the individual and the perfomance (Pizam, 2008). And Cultural Tourism Actual Experience is Cultural tourism experience is a subdivision of special interest tourism (Stebbins, 1996). It is based on the search for and participation in new and deep cultural experiences, whether aesthetic, intellectual, emotional, or psychological (Gunn, 1996). The attractiveness of a tourist destination is becoming more reliant on cultural tourism (Sukanthasirkul and Trongpanich, 2016). Tourist cultural satisfaction is the bases of tourist cultural satisfaction grounded in consumer satisfaction models was used in this study. Many studies have been made to show the relationship between cultural attribute and tourist satisfaction (David, 2017). And the Revisit intention can be understood by analysing the behavioural intention (Pratminingsih et al., 2014) in the tourism sector. A direct relationship between intention engagement and performance behaviour- the stronger intention to engage in behaviour, they are more likely to perform the behaviour (Gortan-Carlin and Krajnovic 2016). Within the tourism segment, this takes form as a repurchase of a tourism benefit or recreational benefit or a return to of a destination or attraction (Pratminingsih et al., 2014).

\section{LITERATURE REVIEW AND HYPOTHESIS DEVELOPMENT}

South Africa is a culturally rich and diverse country, as Desmond Tutu referred to as "The Rainbow Nation" (Chiger, 2016). The original people of the land were the KhoiKhoi and the San. They were later in history joined by the Bantu people, Asian and Europeans during the colonisation of South Africa (South African Culture, n.d.). The Bantu Africans, a term used by the colonist, was made up of northern migraters (Defining the term 'Bantu', 2016). The Bantu migrants are made up of various African cultures which include, Zulu, Xhosa, Sotho, Ndebele, Shangaan and Venda (South African Culture, n.d.) and Post 1994, Archbishop Desmond Tutu coined the term 'Rainbow Nation' to describe South Africa. The term was intended to capture the unity of many cultures and the coming together of people of different nations. South Africa has 11 official languages and many different cultures including the Malays, indigenous African and the KhoiSan as well as Dutch and British settlers, making it one of the most culturally diverse nations in the world (Kellerman, 2014). The first in habitants of South Africa were the Khoi and the San, recently termed collectively as 'Khoisan'. The term 'KhoiKhoi' means 'men of men' or 'people' and was named in opposition to the term 'Hottentot' used by the White colonialists which applied to herding communities in general. 'San' was used to denote those who did not speak the 'Khoi' language. It is estimated that these people had been living in Southern Africa for at least 2000 years before the arrival of European settlers in 1652. Unfortunately, with the invasion came warfare and diseases such as smallpox which is estimated to have wiped out $90 \%$ of the Khoisan community due to their lack of innate immunity. As the years went on and Apartheid took over, they were eventually forced to identify as 'coloured' having only recently regained their identity. This has resulted in much commotion with regards to land restitution act of 1994 which makes no provision for land lost before 1913 (SAHO, 2001).

Initially the Dutch were primarily concerned with fresh produce en route to other countries of interest. Their initial attempt to get cattle and other produce through negotiation failed which resulted in the implementation of slavery. They began to settle in and around the Cape and became what is today known as 'Boers' or 'Afrikaners'. Their attempts to recruit the KhoiKhoi as substantial labour proved to be fruitless which resulted in them using their numbers to place pressure on the Khoi as they expanded. This resulted in them being dispossessed of their land and their independent means of living had come to an end (Education). In 1795, the Cape was occupied by the British in the battle of Muizenburg with the Dutch regaining control only in 1802. This was short lived as the British once again took control of the Cape during the Anglo Boer war to protect the sea route to their Asian empire. Britain held control up until 1961 when South African became a republic which was taken over by the Afrikaners without any black or mixed-race representation. This was known as the 'Apartheid Era' which separated the people of South Africa according to the colours of their skin where each group were treated differently with the white people at the top and the blacks at the bottom. The Apartheid regime continued until 1994 when the first free elections were held (Oliver and Oliver, 2017). The largest part of our country is made up of the Bantu Migrants who arrived at around the same time as the Khoisan from further North, bringing with them an iron age culture and domesticated crops.

From the 1770's, colonists came into conflict with the Bantu speaking chiefdoms and their relatively sophisticated social and economic structures had initially fended off the colonists who lacked the military superiority (Ushakov et al., 2019). Unlike the Khoisan, the black farmers were immune to the diseases of the colonists and did not face the same fate as the Khoisan which resulted in their prosperity and is largely responsible for them making up majority of the black population today. Around 1820, much of the Zulu Kingdom was under the rule of the then innovative King Shaka. Being the majority, obviously the Bantu generation contributes the most to the multi-cultural diversity of our country. The black population of South Africa can be divided into 4 major groups: Nguni (Xhosa, Zulu, Ndebele, Swazi), Sotho, Shangaan-Venda and Tsonga (SAHO, Race and Ethnicity in South Africa, 2011). Westernisation and integration of other cultures and views resulted in much of the cultural loss and movement towards a more modern way of life, however some traditions are still practiced (Pedro, 2008). The Nguni group makes up the majority of Black South Africans, Nguni characteristic individual cone and cylinder rondawels can still be found in rural areas around South Africa (Halpenny et al., 2016). Although cattle are not used for every purpose they were used for before, it is still used as a symbol for status and wealth. It is also used for the payment of a bride (lobola) and extensively in important rituals and events, especially weddings and funerals (Wang, 2017).

The staple diet consists of maize and sour milk. In former times, clothing was mainly made of skin but has been taken over by cotton and woollen blankets with the skins preserved for special occasions (Wahyuningtyas et al., 2019). With regards to religion, there is a focus on Ancestors to which offering are made at all important times during the life cycle (SAHO, Nguni, 2014). The Sotho group makes up the largest proportion of black people second to the Nguni. The main difference between Sotho and Nguni is the contrasting marriage customs with marriage between a bride and groom of a close relation being preferred by Sotho's and frowned upon by the Nguni (Mckercher et al., 2012). The spiritual being that the Sotho most commonly refer to is 'Modimo'. The spiritual ancestors can bring sickness and misfortune to those who forget them or treat them disrespectfully. Today, most churches combine traditional African religion with the doctrines of Christianity (Phillips et al., 2013). Traditionally, men are the heads of the households with women being the farmers and child bearers. Sotho is one of the official languages of South Africa with approximately 8\% of the population using it as their home language (SAHO, Sotho (South Sotho or Basotho), 2011). The Shangaan and their sister tribe, the Tsonga, make up the smallest part of Black South Africans inhabiting mostly Limpopo and Mpumalanga. Generally, both groups are grouped together as one group, i.e. the Tsongas (Wan and Saw, 2013). They are traditionally farmers with Cassava being the main crop of cultivation.

Polygamy is popular amongst this culture with some villages consisting of a single family. One of the main rituals is the face carving ritual which had been used by slave traders as a form of punishment but is now an element of beauty (Rust and Oliver, 1994). One of the main aspects of the Tsonga culture is the story telling which is usually done by the elderly women of the community who keep the history alive. Their full attire is made up of the doek, the neckpiece (vuhlalu), the shirt (yele), the belt (nkhamu) and the Queens (ti 
queeni) (Puh, 2014). Although many of the Khoi women were incorporated into society as low status slaves, the Boers had to find alternate means of labour if they wanted to make the most of the agricultural opportunities. The Indian subcontinent was the main source of slaves and approximately $80 \%$ of slaves came from India (Wan and Saw, 2013). In the second half of the 19th century, two categories were brought to South Africa, the first as indentured labourers in 1860 and later as 'free' Indians who came at their own expense. Emigration, however, was stopped in 1911 and the indentured laborers were free to remain in the country or move back, of which the remaining make up majority of Indians in South Africa today (SAHO, Indian South Africans, 2016).

During Apartheid however, the Indians were also racially categorized, albeit they did not have it as bad as the coloureds and blacks. Majority of the Indians are Hindu, with a large percentage also made up of Muslims, Christians and Sikhs. With a population of approximately 1 million, South African Indians have contributed to the multi-cultural diversity of South Africa (SAHO, Indian South Africans, 2016). As the term 'Rainbow Nation' symbolizes a beacon of hope after the travesties of Apartheid and represents hope for a brighter future South Africans. Although there has been a lot of social and economic growth since the 1994 elections, many South Africans still struggle under the burden of poverty and inequality (Kellerman, 2014).

\section{Innovative Cultural Music and Dance}

Innovation ensures the advances in processes for discovery, experimentation, and the development of existing operations (Mckercher et al., 2012). It involves taking an original idea and adjusting it over a period in accordance to environmental changes (Linders, 2018). By not evolving one's systems according to the changing environment, over time, could lead to a loss of competitiveness (Mckercher et al., 2012). Central to innovation is the understanding one's customer, their patterns in attitudes, and market evolutions (Kontsiwe and Visser, 2019). By understanding the customer and their changes in their attitudes, one will be better equipped to make innovative changes that will be beneficial in the long run (Phillips et al., 2013). To integrate innovation to the context of cultural music and dance in the tourism industry, one must be cognisant of the development of the cultures over the years. South Africa's music industry comprises of ample genres and style (Collision, 2016). If the South African music industry is looked at, the development of the music industry over the years and the influence of its history on cultural music become more apparent. In addition, two main broader categories of music are noted - the music of the white and the music of the blacks. Each had different roots; European music and ethnic tradition, respectively (South Africa,) (Kontsiwe and Visser, 2019). These very distinct roots have over the years borrowed from each other which have resulted in the innovative cultural music.

These two distinct forms of music were a result of South Africa's apartheid government. The apartheid government prohibited the mixing of ethnic groups with the goal of "cultural purity" (Prayag, 2009). This meant that there were bans placed on the mixing of languages and the collaboration between artists of different ethnic backgrounds (Prayag, 2009). Heavy legislation was placed in the music industry to ensure that people of the country listened to music of "their own" people. The covers of albums had to be labelled in accordance to this legislation. It meant that, for example, an album created by a black person must be in their native language and has go be labelled "Zulu" (Prayag, 2009). Innovative Cultural Festivals, the largest arts festival takes place in Grahamstown annually (About the National Arts Festival, n.d.). It is known as the National Arts Festival. This festival is open to anyone who would like to showcase their drama, dance, theatre, comedy, music. Forged by the traditions and cultures of the lands, festivals might become a part of an area's make-up. Festival tourism is yet another aspect of tourism, festival tourism is one of the fastest growing segments of the world's leisure industry". It is by festivals that a unique opportunity is created by which visitors may be provided an opportunity to have cultural experiences for both leisure and social reasons. Cultural heritage tourism is seen as one of the major development opportunities for Africa. In the South African context, festival tourism is not very prominent even though it may be the most prevalent type of tourism in the rest of the world.

This is especially noticeable when one explores the festivals of South Africa. If one is to do a "Google Search" on "Cultural festivals in South Africa", there is not much representation of indigenous cultures in South Africa to those who would be searching for such information. An example would be, found on is the Kaapse Klopse (Prayag, 2009). a listing of South Africa's top ten festivals, not one of the festivals listed have any ties to indigenous cultures. The list includes; the Knysna Oyster Festival, Hermanus Whale Festival and the Oppikoppi Bushveld music festival. There is a list of festivals occurring in South Africa month to month for the year, a single festival includes indigenous elements, this festival being "Macufe", which would showcase music in local languages. On the website "Culture trip", festivals are listed according to the regions of South Africa, the only festival involving South African local culture is that of the Cape Town, the Minstrels. Other than that, no inclusion of indigenous cultures is listed or propagated. "South Africa Holiday and Festivals", once again the Minstrels of Cape Town are mentioned, whilst the Royal Reed Dance features as well. The rest of the list is the Arts Alive festival, Oppikoppi, The Jacaranda Festival, Knysna Oyster festival and the Cape town international jazz festival. In an article featured in, a quote by Samuel Nassimov, managing director of Premier hotels and resorts, states" the country has a number of sites that serve as a reminder of our unique past, how far we've come as a nation and how much further we need to go in building a better South Africa for all”. The webpage then goes on to list cultural attractions in different cities, not making mention of any cultural festivals.

\section{Cultural Tourism Expected Experience and Actual Experience}

Cultural tourism experience is a subdivision of special interest tourism (Stebbins, 1996). It is based on the search for and participation in new and deep cultural experiences, whether aesthetic, intellectual, emotional, or psychological (Stebbins, 1996). The attractiveness of a tourist destination is becoming more reliant on cultural tourism (Sukanthasirkul and Trongpanich, 2016). Thus, to attain a competitive advantage in the tourism industry, developments of authentic, enriching and memorable new experiences are dire to the sector (Dalton, 2011). It should be noted that the attraction of a cultural tourism site does not merely depend on the predilection to discover physical attractions (Prayag, 2009). The experience further includes once personal and emotional bond with the heritage (Wang, 2017).

Therefore, to offer a cultural experience that meets the needs of a consumer, both the core physical asset of cultural touris $m$ needs to be fulfilled, as well as the experiences that target higher self-induced need, which go beyond the tangible offering (Xu, et., al 2009). In Dalton's article, she emphasizes the importance the destination having a special meaning to the tourist to create a favourable experience for the consumer. She refers to an article by Brunner-Sperdin and Peters (2009), which highlights their argument that the experience value of a tourism offering is the overriding factor influencing a consumer's motivation to visit an attraction. The composition of a tourist experience encompasses both a tangible and intangible constituent. Since the tourist experience is multi-faceted it is dire that each element-the tangible and intangible- are cautiously outlined to meet both the expected and actual experience that the tourist has (Dalton, 2011).

Due to the multifaceted nature of tourism experience, extensive research is still being done to understand how the various contributors to the experience can be understood to create a uniform management of a tourist's experience. According to Dalton, (2011), two prevailing issues often confront both academics and tourism practitioners when trying to understand cultural experience. This is that 
the understanding of what comprises a commercial experience is meagre (Beerli and Martin, 2004), and the appropriate manner to create and put into practice the new desire for tourism experiences (Morgan et al., 2009).

\section{Tourist cultural satisfaction}

The basis of tourist cultural satisfaction is rooted in consumer satisfaction models. Many studies have been made to show the relationship between cultural attributes and tourist satisfaction. Tourists who embark on journeys intending to have cultural experiences in the place visited may complete their trips either feeling that they have satisfactorily experienced said culture or perhaps feeling that the experience was deficient in some way (Wan and Saw, 2013). Ample research has been conducted to develop an understanding of the tourist's cultural satisfaction as it is relevant in the realm of tourism, proving to be a useful tool in gauging the success of a destination in the opinion of visitors (Stebbins, 1996). It may also be used as an indicator of the visitor's intention to revisit a destination. To begin with, cultural tourism may be defined as, "Implying the notion of patrimony, represented by both the material and immaterial components of the identity of any society" (Sukanthasirkul and Trongpanich, 2016). Plesoianu et al further go on to detail what would qualify as the material and immaterial heritage listing museums, monuments, etc. as the material while mentioning that cultural traditions, holidays and accumulated traditions would form the latter. Depending on what the initial intention of the tourist was, they may find that their trip culturally satisfactory or not (Sukanthasirkul and Trongpanich, 2016). There may also be situations in which the intention had not been to embark on cultural tourism at all but because of the nature of the destination, they still had experienced cultural facets and were satisfied with the experience even though it was not planned. Plesoinau observes the relations that exist between those who would be the inclined towards embarking on cultural tourism by choice and draws some interesting conclusions. Cultural tourism practices vary significantly, having specifically investigated the practices in the Brasov County, bringing attention to the fact that cultural tourism is based on the facilities that the tourist has at their disposal, hence, having a basis of touristic material is vital for the flourishing of cultural tourism activities (Dalton, 2011).

Their research goes on further to recommend that to improve cultural tourism in an area, the improvement of infrastructure and transport networks should be created, coupled with the provision of tourist information on diverse cultural objectives. too, observes that cultural tourism is a substantial facet of tourism as well as addresses the economic and cultural impact of tourism in tourism marketing, stating that the beneficial economic impact of it is obvious (Prayag, 2009). The study also presents the positive cultural impact that cultural tourism may have, listing the increase in people's confidence, allowing people an influence over how others may perceive them, stimulation of the interests and confidence in the arts, development of pride in local traditions and cultures and the provision of a unique and genuine source of enjoyment. He also makes mention of the statistics from the World Tourism Organization, mentioning that almost $40 \%$ of tourist trips are related to cultural tourism. stated, on cultural tourism, that it is an aspect that is recognized and managed by the local community itself and serves to not only diversify the local economy but also creates additional value and allows for the resilience of the community to be strengthened. It is further stated that cultural tourism proves beneficial in that cultural heritage, if adequately managed, could be instrumental in promoting social inclusion, creating intercultural dialogue, forming the identity of the area, improving the overall quality of the environment, the provision of social cohesion as well as stimulating the development of tourism which has the ability to create jobs and draw in investment (Rogerson and Collins, 2019). All of which would be useful in the South African context.

\section{Tourist revisit intention}

Revisit intention can be understood by looking at behavioural intention (Chang et al., 2012). A direct relationship between intention engagement a performance behaviour- one stronger intention to engage in a behaviour, they are more likely to perform the behaviour (Pratminingsih, et al., 2014). Within the tourism and diversion segments, this takes frame of a repurchase of a tourism benefit or recreational benefit or a return to of a destination or attraction (Bole, et al., 2017). Revisit intention can be understood by looking at behavioural intention. A direct relationship between intention engagement a performance behaviour, one stronger intention to engage in a behaviour, they are more likely to perform the behaviour. Within the tourist and diversion segments, this takes frame of a repurchase of a tourism benefit or recreational benefit or a return to of a destination or attraction. The intention of a tourist to revisit a destination has been an area that has had some investigation undertaken so as to develop a better understanding of tourist behaviour. This factor would also be one of significance as it allows for there to be a guide formed with regards to how to not only attract tourists initially but also provide an experience that would create the desire to return to the tourist destination (Pizam et al., 2008). Observed by , an area may be enhanced with regards to tourism marketing when there is an element of place attachment involved. Tsai then further explains that although this may prove true, there is much complexity that further develops as attachment is a concept difficult to conceptualize as there exists within it inherent diversities. The model developed by Tsai portrayed that there exists a comprehensive attachment that encompasses a "holistic tourist experience", containing facets such as self-expressiveness, emotional pleasure, physical growth and communal awareness. He concludes further that as such, place attachme nt may be a powerful tool that influences a tourist's revisit behaviour. Tsai defines 'place attachment' as, "the emotional and psychological bonds formed between an individual and a particular place. It is then further explained how it is then that place attachment may be considered a prominent tourism marketing strength which in turn has a substantial impact on a tourist's loyalty towards a destination as well as their revisit behaviour. A study by confirms that place attachment may indeed serve as a potential predictor of one's plans to return to a specific destination.

Tsai also draws a similarity between interpersonal attachment and place attachment, drawing on the fact that place attachment can bond the tourist psychologically and emotionally with the destination. Some benefits that would influence the attachment that Tsai mentions include, amongst others; the functional benefits of the destination, emotional benefits, uniqueness, trust (i.e. the visitor has confidence in the destination and feels a sense of security), attractiveness and self-connection. As such, it is suggested that efforts should be made to attempt to mold and translate the symbolic meaning a destination may have into a representation that suits the socio-cultural context and matches with the tourist's desires they might harbour as well as the dreams and aspirations that they might have in mind. point out that the service one experiences on a tourist visit has a valuable influence on the evaluation and satisfaction of the consumer (Wang, 2017). They also make known that the current global trend that exists with regards to partaking in heritage tourism, observing that it is becoming more popular than before, indicating at the growing numbers that have been observed.

The notion said to be attributed to "a more visitor-oriented development that emphasizes consumer preferences and quality of personal experience",. Chen and Chen, (2010) also advise that the provision of high-quality satisfying experiences that could be perceived as good value by visitors would be a manner by which to increase visitors' behavioural intentions suggest that a way to ensure sustainability in destinations is to foster loyalty amongst the visitors, again reinforcing the need to have consumer satisfaction. Loyalty is then manifested through recommendation by those who have visited to others, a positive spreading of information amongst people, and repeat visitation (Wang, 2017). The research also draws attention to the fact that promoting repeat visitation is especially desirable as it costs less than it 
would to draw in new visitors. The paper also makes mention of the need that exists to increase revisits and suggests that there should be efforts made towards the creation of desire and need which could be done by developing more attractions and amenities (Apostolakis, and Jaffry, 2005). It is also stressed that revisit need, and desire should be sought from a wide market to develop the tourism industry. The paper also suggests that to encourage revisits of a destination there should be a positive destination image created, as well as ensure that there is consistent quality service, amenities and a variety of events and programs to attract re-visitation.

\section{MATERIALS AND METHODS}

The research philosophy that has been adopted is positivism. Positivism research adopted quantitative research methods that tested hypothesis deductively and examined possibilities to reach a specific, logical conclusion (Chi and Qu, 2017). The hypothesis was tested by analysing the influence that the dependent and independent variables have. This study made use of a quantitative research technique that generally involved the collection of primary data from a target population of those that have consumer experience in cultural tourism in the Gauteng Province. Participants were male, female, and other. In addition, South African citizens and non-south African citizens were included in the population. A random probability sampling was used. The sample size consisted of 200 participants. Three hundred questionnaires were distributed to participants from a variety of social and financial backgrounds. 50 of the issued questionnaires were not completed and a further 50 had to be discarded due to errors in completion. This was done for the purpose of capturing the wider population of consumers of the tourism sector. Quantitative primary research was conducted using a self-administered questionnaire to collect data. The questionnaire design allowed the determination of the Confirmatory Factor Analysis indices, Chi-Square/degree of freedom, Comparative Fit Analysis and the Incremental Index of Fit. A cross-sectional study was conducted due to time limitations which restricted the use of longitudinal studies. The population refers to the total group and or elements of interest to the researcher which the researcher sets out to interrogate with a view to obtain information and making informed inferences (Best and Khan, 2003).

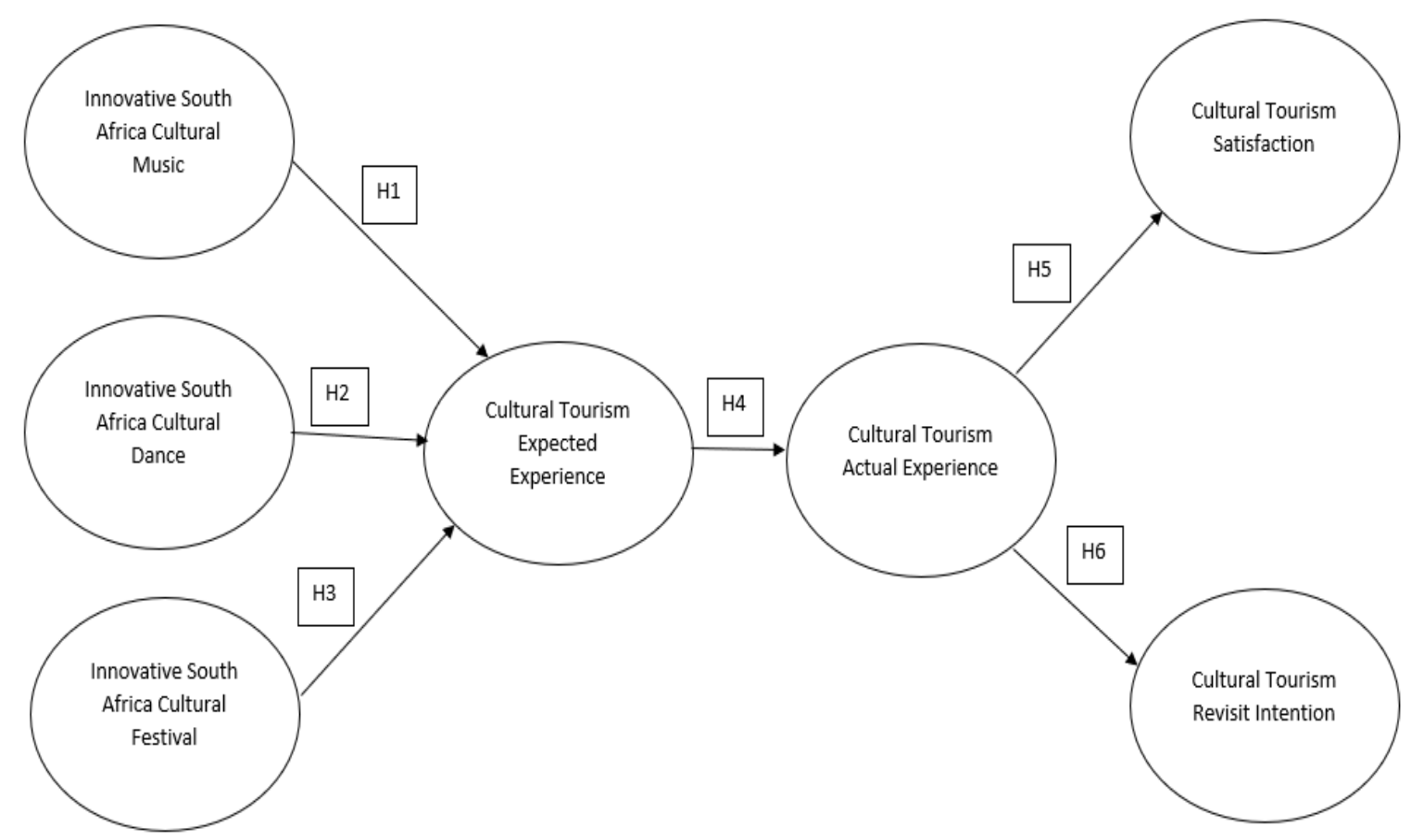

Figure 1. Conceptual Framework and Hypothesis Development

H1: There is a positive relationship between innovative South African Cultural Music and Cultural Tourism Expected Experience H2: There is a positive relationship between innovative South African Cultural Dance and Cultural Tourism Expected Experience H3: There is a positive relationship between innovative South African Cultural Festivals and Cultural Tourism Expected Experience

H4: There is a positive relationship between Cultural Tourism Expected Experience and Actual Cultural Experience

H5: There is a positive relationship between Actual Cultural Tourism Experience and Tourist Cultural Satisfaction

H6: There is a positive relationship between Actual Cultural Tourism Experience and Cultural Tourism Revisit Intention

\section{RESULTS DISCUSSIONS}

The overall finding implies that each research variable has its unique way towards the contribution and the influence of innovative African cultures in the south African tourism industry. Sample Description-The demographic profile is given of the respondents of age and gender type of travel and source of information and type of cultural tourism experienced. Thereafter the average mean standard deviation of each research construct is given.

The reliability of the instrument was tested by making use of the Cronbach Alpha. According to Hair et al, a value greater than or equal to 0.7 represents an acceptable reliability of the instrument. The closer the Cronbach Alpha value is to 1, the more reliable the internal reliability of the variables is. In Table 22, all the variables were above the recommended threshold. The highest value was 0.913 and the lowest 0.770 . All the measures are, therefore, reliable. Composite reliability According to Hair .et al, an acceptable value is any number greater than 0.7. If values are 0.6 and higher, they can also be considered as reliable. The lowest CR was 0.48 , and the highest was 0.86 . Not all the variables met the required criteria. Average variance Extracted. The average variance estimate measures the $s$ hared common variance in a latent variable (Fornell and Larker, 1981). For the construct to be considered reliable, the AE should be a value greater than 0.4 (Fraering and Minor, 2006). All the variances for the variables were in line with this requirement, and where thus, reliable. The variances extracted for this study ranged from 0.48 to 0.87 . 
Table 1. Summary of demographics

\begin{tabular}{|c|c|c|c|c|}
\hline Gender & Age & & & \\
\hline & Frequency & Percentage & & Frequency \\
\hline Male & 78 & 39 & $20-21$ & 55 \\
\hline Female & 119 & 59.5 & $26-30$ & 52 \\
\hline Prefer not to say & 3 & 1.5 & $31-35$ & 43 \\
\hline Total & 200 & 100 & $36-40$ & 21 \\
\hline Citizenship & $41-45$ & 7 & \multicolumn{2}{|c|}{3.5} \\
\hline Non-South African & 5 & 2.5 & $46-50$ & 8 \\
\hline South African & 195 & 97.5 & $51-55$ & 14 \\
\hline Total & 200 & 100 & $56-60$ & 0 \\
\hline Marital status & Total & 200 & \multicolumn{2}{|c|}{100} \\
\hline Married & 36 & 28 & \multicolumn{2}{|l|}{ Type of travel } \\
\hline Single & 106 & 50 & Inbound travel & 57 \\
\hline None of the above & 44 & 22 & Outbound travel & 12 \\
\hline Total & 200 & 100 & Domestic & 83 \\
\hline Type of cultural tourism experienced & International & 48 & \multicolumn{2}{|c|}{24} \\
\hline Purposeful & 18 & 9 & Total & 200 \\
\hline Serendipitous & 44 & 22 & \multicolumn{2}{|c|}{ Sources of information } \\
\hline Casual & 39 & 19.5 & TV & 9 \\
\hline None of the above & 36 & 18 & Newspaper & 22 \\
\hline \multirow[t]{5}{*}{ Total } & 100 & 200 & Travel Agent & 30 \\
\hline & & & Friends/ Relations & 72 \\
\hline & & & Tour books/guides & 33 \\
\hline & & & Other & 34 \\
\hline & & & Total & 200 \\
\hline
\end{tabular}

Table 2. Summary of descriptive statistics

\begin{tabular}{|c|c|c|c|c|c|}
\hline Research Construct & Cronbach's Test & C.R Value & AVE Value & \multicolumn{2}{|c|}{ Factor Loading } \\
\hline \multirow{3}{*}{ IM } & IM2 & 0.604 & \multirow{3}{*}{0.781} & \multirow{3}{*}{0.80} & \multirow{3}{*}{0,57} \\
\hline & IM3 & 0.744 & & & \\
\hline & IM4 & 0.570 & & & \\
\hline \multirow{4}{*}{ ID } & ID1 & 0.683 & \multirow{4}{*}{0.855} & \multirow{4}{*}{0.86} & \multirow{4}{*}{0.60} \\
\hline & ID2 & 0.651 & & & \\
\hline & ID3 & 0.841 & & & \\
\hline & ID4 & 0.670 & & & \\
\hline \multirow{3}{*}{ IF } & IF1 & 0.663 & \multirow{3}{*}{0.816} & \multirow{3}{*}{0.80} & \multirow{3}{*}{0.57} \\
\hline & IF2 & 0.733 & & & \\
\hline & IF3 & 0.634 & & & \\
\hline \multirow{3}{*}{ CEE } & CE3 & 0.597 & \multirow{3}{*}{0.770} & \multirow{3}{*}{0.73} & \multirow{3}{*}{0.48} \\
\hline & CE4 & 0.585 & & & \\
\hline & CE5 & 0.630 & & & \\
\hline \multirow{4}{*}{ CEA } & CE1.3 & 0.665 & \multirow{4}{*}{0.809} & \multirow{4}{*}{0.48} & \multirow{4}{*}{0.73} \\
\hline & CE1.4 & 0.669 & & & \\
\hline & CE1.5 & 0.640 & & & \\
\hline & CE1.6 & 0.546 & & & \\
\hline \multirow{4}{*}{ CS } & CS1 & 0.654 & \multirow{4}{*}{0.841} & \multirow{4}{*}{0.45} & \multirow{4}{*}{0.76} \\
\hline & $\mathrm{CS} 2$ & 0.633 & & & \\
\hline & CS6 & 0.690 & & & \\
\hline & CS7 & 0.758 & & & \\
\hline \multirow{10}{*}{ TI } & TI1 & 0.787 & \multirow{10}{*}{0.913} & \multirow{10}{*}{0.63} & \multirow{10}{*}{0.87} \\
\hline & TI2 & 0.733 & & & \\
\hline & TI3 & 0.699 & & & \\
\hline & TI4 & 0.654 & & & \\
\hline & TI5 & 0.681 & & & \\
\hline & TI6 & 0.708 & & & \\
\hline & TI7 & 0.504 & & & \\
\hline & TI8 & 0.792 & & & \\
\hline & TI9 & 0.792 & & & \\
\hline & TI10 & 0.581 & & & \\
\hline
\end{tabular}

Table 3. The correlation matrix for the study is illustrated below

IM

\begin{tabular}{|c|c|c|c|c|c|c|c|}
\hline IM & & ID & IF & $\mathrm{CE}$ & CEA & CS & TI \\
\hline$\overline{\mathrm{IM}}$ & Pearson Correlation & 1 & & & & & \\
\hline ID & Pearson Correlation & $.718 * *$ & 1 & & & & \\
\hline IF & Pearson Correlation & $.476^{* * *}$ & $.524 * *$ & 1 & & & \\
\hline$\overline{\mathrm{CE}}$ & Pearson Correlation & $.169^{*}$ & $.165^{*}$ & .102 & 1 & & \\
\hline CEA & Pearson Correlation & .046 & -.003 & $-.177 *$ & $.745 * *$ & 1 & \\
\hline $\mathrm{CS}$ & Pearson Correlation & $.184 * *$ & .006 & -.074 & $.429 * *$ & $.550 * *$ & 1 \\
\hline TI & Pearson Correlation & $.251 * *$ & .090 & .128 & $.401 * *$ & $.453 * *$ & $.829 * *$ \\
\hline
\end{tabular}


To achieve high discriminate validity, values of 1 are the goal, however, 0,8 is accepted (O'Rourke and Hatcher, 2013). From the table above, it is noted that all the inter-correlation values deviate from one. In addition, all are less than 0.8 . Based on this, it can be said that all the correlations were significant.

Table 4. Model Fit Indices

\begin{tabular}{|c|c|c|c|c|c|c|c|c|}
\hline Model Fit Indice & Chi Square & GFI & CFI & TLI & IFI & RFI & NFI & RMSEA \\
\hline Indicator Value & 2.814 & 0.738 & 0.846 & 0.797 & 0.852 & 0.717 & 0.787 & 0.095 \\
\hline
\end{tabular}

The Chi Square for the model was 2,814, which is less than 3. This indicates that the model is good. Baseline values. According O'Rourke and Hatcher, 2013), the NFI, IFI, TLI, and CFI should be greater than 0.9. The baseline value for this model range from 0.717 and 0.852 . According to Hair et al (2006), baseline values above 0.8 are marginally acceptable. The NFI is 0.787 , which is below 0.9 which indicate that the model needs to be re-specified (Huand Bentker, 1995).The IFI and CFI are above 0.8 and indicate that the model is marginally acceptable.The GFI value is 0,738 , which is below the acceptable value. This indicates an unacceptable model fit (Fraering and Minor, 2006). The RMSEA should be less than or equal to 0.05 to be a good model, or 0,08 to be adequate (Browne and Cudeck, 1993). The value for this study is 0.095 which does not meet the model requirements, but it is a close fit.

Table 5. Summary of Indices

\begin{tabular}{|c|c|c|c|}
\hline Model Fit Indices & Acceptable Threshold & Study Values & Comment \\
\hline Chi-Square & $<3$ & 2.814 & Acceptable \\
\hline CFI & $>0.9$ & 0.846 & Marginally Acceptable \\
\hline GFI & $>0.9$ & 0.738 & Close Fit \\
\hline NFI & $>0.9$ & 0.787 & Close Fit \\
\hline IFI & $>0.9$ & 0.852 & Marginally Acceptable \\
\hline TLI & $>0.9$ & 0.797 & Close Fit \\
\hline RMEAS & $<0.08$ & 0.095 & Close Fit \\
\hline
\end{tabular}

Path modelling and hypothesis testing

The higher the path coefficient value, the greater the relationship between the variables being tested (McIntosh and Gonzalez-Lima, 1994). The path coefficients $d=$ indicate the strength between the variables. The hypothesis was tested at a $95 \%$ level of significance and supported hypotheses were shown by asterisk (***). Values which displayed a significance level $\mathrm{p}<0,05$ were marked with $*$, significance level $\mathrm{p}<0.01$ were marked with $* *$, and significance level $\mathrm{p}<0.001$ were marked $* * *$.

Table 6. The results for the hypotheses testing are represented in table below

\begin{tabular}{|c|c|c|c|c|}
\hline Hypothesis Relationship & Hypothesis & Path Coefficient & P Values & Outcomes \\
\hline IM>CE & H1 & 0.396 & $* * *$ & Supported and Significant \\
\hline ID>CE & H2 & 0.161 & 0.015 & Not Supported and Insignificant \\
\hline IF>CE & H3 & -0.216 & 0.002 & Not Supported and Insignificant \\
\hline CE>CEA & H4 & 0.842 & $* * *$ & Supported and Significant \\
\hline CEA>CS & H5 & 0.540 & $* * *$ & Supported and Significant \\
\hline CEA>TI & H6 & 0.471 & Supported and Significant \\
\hline
\end{tabular}

Drawing from the above, the relationship between CE and CEA, H4, is the strongest as CE has a strong positive relationship on CEA, with a path coefficient of 0.842 and a $p<0,0001$ level of significance. H3 displayed a negative relationship, which was also the weakest and it was also not supported. H1, H4 and H6 were all supported and significant. H2 was supported yet was insignificant

H1: There is a positive relationship between innovative South African Cultural Music and Cultural Tourism Expected Experience. Based on the findings presented, it indicates that the hypothesis (H1) is supported and significant. It found that there is a positive relationship between innovative cultural music and customer expected experience. This means that a positive attitude toward innovative South African cultures will most probably have a positive effect on cultural Tourism Expected Experience. The hypothesis agreed with previous studies that the encounters that tourist have with innovative cultural dance affects the expected experience is the perceived value that a tourists have in mind in relation to the costs and benefits that It can be concluded that by expecting a positive interaction with innovative cultural dance, music and festivals will impact the expected cultural tourism expectation positively.

H2: There is a positive relationship between innovative South African Cultural Dance and Cultural Tourism Expected Experience. The second hypothesis, $\mathrm{H} 2$ was found to be supported and insignificant. This implies that there is a positive relationship between the variables. However, the effect that the one variable has a very small effect on the other variable. The hypothesis agrees with previous studies that the encounters that tourist have with innovative cultural dance affects the expected experience is the perceived value that a tou rists have in mind in relation to the costs and benefits that It can be concluded that by expecting a positive interaction with innovative cultural dance, music and festivals will impact the expected cultural tourism expectation positively.

H3: There is a positive relationship between innovative South African Cultural Festivals and Cultural Tourism Expected Experience. A negative relationship between the variables were found for $\mathrm{H} 3$. The hypothesis was both not supported and insignificant. This means that regardless of the impact on innovative cultural festivals on expected cultural tourism experience will not be affected. The hypothesis was not in agreement with previous studies that the encounters that tourist have with innovative cultural dance affects the expected experience is the perceived value that tourists have in mind in relation to the costs and benefits.

H4: There is a positive relationship between Cultural Tourism Expected Experience and Actual Cultural Experience. Based on the finding, hypothesis 4 was both significant and supported. This indicates that an increase in the expected experience, leads to an increase in the actual experience. This confirmed that the actual cultural experience can be understood by looking at the perceived value. This can be defined as "the overall assessment of the utility of a product based on the perceptions of what was received and what is given" (Frey, (2010). 
The expected experience is the perceived value that a tourists have in mind in relation to the costs and benefits that they have developed mentally. If a tourist has high expectations, and they are met, this will lead to a stronger actual cultural experience.

H5: There is a positive relationship between Actual Cultural Tourism Experience and Tourist Cultural Satisfaction. Hypotheses 5 was found to be supported and significant. An increase in the actual experience leads to an increase in customer satisfaction. This confirms that customer satisfaction in a tourism context can be described as a function of the pre and post travel experiences. If the tourists have a positive experience in terms of their actual and expected expectations, this will lead to a positive satisfaction level from the tourist.

H6: There is a positive relationship between Actual Cultural Tourism Experience and Tourist Revisit Intention. Hypotheses 6 was found to be supported and significant. An increase in the actual experience leads to an increase in revisit intention. This agreed with the previous studies that one of the factors which contribute to whether a tourist has an intention to revisit a destination, is indeed the tourists' experience. I the tourist's expectations are met, and they have a positive experience, they are more prone to revisit the destination Yuan et, al., 2007).There exists a positive relationship between tourists' experience and intention to revisit the tourism destination This means that the experience of the tourist will influence whether a tourist will have an intention to revisit the destination. In addition, the theory of planned behaviour can be used as a theoretical backing to further understand the tourists; intention to revisit the destination.

Practical managerial implications and recommendations- The results may be used by managers and marketing personal within the cultural tourism industry to formulate strategies to better market cultural tourism products. In addition, the tourism industry can use this research to further understand their customers and their expectations, this will help to provided more tailored products and services that will meet and exceed tourist's expectations which will lead to revisit intention and thus a stranger brand image for South African tourism. For the South African tourism to remain completive and sustainable in the long run, they need to ensure that they embrace more cultural experiences as opposed to just site-seeing. Marketing Contributions - the research findings of the study provide valuable practical implications for marketers to develop better customer retention strategies. the findings also provide a contribution to the marketing environment on tourism service providers behaviours by determining that most persons that utilise or access tourism services get information from a variety of sources with many respondents use social media innovations. Thus, allowing marketers to underst and the consumer behaviour of the consumer and competition to the tourisms segment. Furthermore, the study findings indicate that consumers are attitudinally loyal, thus marketers can act on this attitudinal loyalty through establishing cultural tourisms brands programs, discounts, incentives as well as added value in order to get the consumer to revisit the tourism destinations, thus establish behavioural cultural tourisms loyalty priority for marketers to win their business and heart of tourists. The results of the study were in line with both theoretical grounding factors, the theory of panned behaviour and its effect on revisit intention and the theory of customer satisfaction. Its highlighted how the experiences that the tourist had will impact the revisit intention and satisfaction. Limitation and future research Most participants were from Gauteng. This therefore, did not provide a full representation of tourist who visited the Gauteng Province for cultural tourism Limitations- The study does not come without its limitations and the limitations for the study are the exclusion of the greater Johannesburg region, in which further research can be examined in regard to the variables of cultural tourism that where analysed and determined. In further studies cultural identification, tourism cultural quality and other precursor of tourism cultural experience that were excluded from the study can be analysed also be included. Future research -The future research can look at the greater Southern African region since it also cuts across cultures and share tourism attractions and destinations.

\section{CONCLUSION}

South Africa is a culturally rich nation, however, through this research it was noted that true African experiences are still a market that is underutilized. It can be understood that South Africa offers a Western experience in and African setting. It will be extremely beneficial for the South African tourism industry to capitalise on a more authentic African cultural experience. Theoretically, this study contributes to literature in tourism marketing, also the study contributes academically by confirming the relationships of variables in the research conceptual model. This indicates that the elements of cultural tourism, actual experiences are precursor of cultural tourism entertainment that can be determined through brand revisit intentions. Tourists are more interested in experiencing the cultures of their tourism destinations and this will impact the level of satisfaction that they acquire, as well as their overall revisit intention.

\section{Aknowlegments}

The authors acknowledge to anonymous reviewer/s for their thoughtful suggestions and comments.

\section{REFERENCES}

Apostolakis, A., \& Jaffry, S. (2005). A choice modeling application for Greek heritage attractions. Journal of travel research, 43(3), 30-318.

Babbie \& Earl, R. (2010). The Practice of Socia Research. Belmont. Social Science Fifth Edition, 566 Belmont, CA, USA.

Baker, D.A., \& Crompton, J.L. (2000). Quality satisfaction and behavioural intentions. Annuals of Tourism research, 785-804.

Beerli, A., \& Martín, J. (2004). Factors Influencing Destination Image. Annals of Tourism Research. 31(3): 657-681.

Best, J.W., \& Kahn, J.V, (2003). Research in Education. New Delhi, Prentice Hall of India Pvt. Ltd., 107.

Bole, D., Hribar, M.S., \& Pipan, P. (2017). Paticipatory research in community development: A case study of creating cultural tourism products. AUC Geographica, 164-175.

Bryman, A. (2007). Business Research Methods. Oxford : Oxford University Press.

Browne, M.W., Cudeck, R. (1993), Ways of Assessing Model Fit. In: Bollen, K.; Long, J., editors. Testing Structural Equation Models. Sage; Newbury Park, CA: 1993. p. 136-162.

Burger, C.C., Dohnal, M., Kathrada, M., \& Law, R. (2001). A practitioners guide to time-series methods for tourism demand forcasting- a case study of Durban South Africa. Tourism Management, 2, 22 No.4 pp.403-409.

Chang, L.L., \& Backman, K.F. (2012). An Investigation of Creative Tourists' Experience and Revisit Intention. Tourism Travel and Research Association. Advancing Tourism Research Globally, 23, https://scholarworks.umass.edu/ttra/2012/Visual/23.

Chen, C.F., \& Chen, F.S. (2010). Experience quality, perceived value, satisfaction and behavioral intentions for heritage tourists. Tourism management, 31 , 29-35.

Chi, C.G.Q., \& Qu, H. (2008). Examining the structural relationships of destination image, tourist satisfaction and destination loyalty: An integrated approach. Tourism Management. 29: 624-636.

Chiger, N. (2016). Why is SA Called the Rainbow Nation. Retrieved from Quora: https://www.quora.com/Why-is-South-Africa-called-rainbow-nation.

Collision, L.S. (2016). Culture Trip. Retrieved from A Brief Guide to South African Music: www.thevulturetrip.com/africa/south-africa/articles/ abrief-guideto-south-african-music. 
Collison, L.S. (2016, 09 20). A Brief Guide To South African Music. Retrieved from Culture Trip: https://theculturetrip.com/africa/south-africa/articles/abrief-guide-to-south-african-music/

Dalton, R. (2011). Cultural Tourism Experiences A Development Framework. 6.

David Scowsill (2017). Retrieved from World Travel and Tourism Council: https://www.wttc.org/-/media/files/reports/economic-impact-research/countries2017/southafrica2017.pdf.

Fraering, M., \& Minor, M.S. (2006). Sense of community: An exploratory study of US consumers of financial services. International Journal of Bank Marketing 24(5):284-306.

Frey, C. (2010). Innovation Management.ze. Retrieved from Whatb is and Innovation Culture?: www.innovationmanagement.se/imtool-articles/what-is-aninnovation-culture.

Fornell, C., \& Larcker, D.F. (1981). Evaluating structural equation models with unobservable variables and measurement error. Journal of Marketing Research, 18 (139-50. (3) (PDF) Factor analysis and discriminant validity: A brief review of some practical issues. Available from: https://www.researchgate.net/ publication/40500590_Factor_analysis_and_discriminant_validity_A_brief_review_of_some_practical_issues.

Gortan-Carlin, I.P., \& Krajnovic, A. (2016). Music as a Tourist Product- The Management and Marekting Model. Management International conference, 209.

Gunn, C. (1972). Vacationscape. Destination tourist regions. Washington DC..

Halpenny, E.A., Kulczycki, C., \& Moghimehfar, F. (2016). Factors affecting destination and event loyalty: examining the sustainability of a recurrent smallscale running event at Banff National Park. Journal of Sport and Tourism, 233-262.

Kellerman, S. (2014). The Rainbow Nation.

Kontsiwe N., \& Visser G. (2019). Tourism as a vehicle for local economic development in small towns? when things go wrong: the case of aliwal north, South Africa. GeoJournal of Tourism and Geosites, 27(4), 1334-1346.

Linders, B. (2018). InfoQ. Retrieved from Growing an Innovative Culture: www.infoq.com/articles/growing-innovative-culture

Merwe, C.D. (2016). Tourist guide's perceptions of cultural heritage tourism in South Africa. Bulletin of Geography. Socio-economic Series, 1.

Morgan, M., Elbe, J., de Esteban Curiel, J. (2009). Has the experience economy Arrived? The views of destination managers in three visitor-dependent areas. International Journal of Tourism Research, Vol. 11, pp. 201-216.

Munien, S., Gumede, A., Gounden, R., Bob U., Gounden, D., \& Perry, N.S. (2019). profile of visitors to coastal and marine tourism locations in cape town, south africa. GeoJournal of Tourism and Geosites, 27(4), 1134-1147.

McIntosh, C.N., \& Gonzalez-Lima, (1994). Rethinking Fit Assessment in Structural Equation Modeling: A Commentary and Elaboration on Barrett (2007). Personality and Individual Differences 2007; 42:859-67.

McKercher, B., Denizi-Guillet, B., \& Ng, E. (2012). Rethinking Loyalty. Annals of tourism research, 671-686.

Pedro, Diedericks. (2008). Culture, language and niche publications in South Africa. Global Media Journal. African Edition Vol 2 (2)

Phillips, W.J., Wolfe, K., Hodur, N., \& Leistritz, F.L. (2013). Tourist Word of mouth and revisit intentions to rural tourism destinations: a csae of North Dakota USA. International Journal of tourism research, 93-104.

Pizam, A., Neumann, Y., \& Reichel, A. (2008). Dimensions of tourist satisfaction with a destinatioon area. Annuals of Tourism Research, 5(3), 314-322.

Plesoianu, D.M., Sandu, C., \& Popescu, A. (2017). Aspects of cultural tourism in Brasov County with a specila look at the period 2015-206. Scientific Papers Series Management, Economic Engineering in Agriculture and Rrural Development, 17(3), 287-293. Retrieved 2018.

Pratminingsih, S.A., Rudatin, C.L., \& Rimenta, T. (2014). Roles of motivation and destination image in predicting tourist revisit intention: a case of Bandung - Indonesia. International Journal of Innovation, Management and Technology. 5(1): 19-24.

Prayag, G. (2009). Tourists's evaluations of destination image, satisfaction, and future behavioral intentions - The case of Mauritius. Journal of Travel \& Tourism Marketing. 26: 836-853.

Puh, B. (2014). Destination image and tourist satisfaction: The case of a Mediterranean Destination. Mediterranean Journal of Social Sciences. 5(13): 538-544.

Rogerson, C.M. \& Collins, K.J.E. (2019). Entrepreneurs in craft beer and tourism: perspectives from South Africa. GeoJournal of Tourism and Geosites, $27(4), 1158-1172$.

Rust, R.T., \& Oliver, R. (1994). Service quality: Insights and managerial implication from Frontier. Thousand Oaks.

Sukanthasirkul, K., \& Trongpanich, W. (n.d.). Cultural Tourism Experience on Customer Satisfcation: Evidence from Thailand.

Stebbins, R.A. (1996). Cultural tourism as serious leisure. Annals of Tourism Research, 23(4), 948-950.

Oliver, E., \& Oliver W.H., (2017). 'The Colonisation of South Africa: A unique case', HTS Teologiese Studies/Theological Studies 73(3), a4498

O'Rourke, N., \& Hatcher, L. (2013). A Step-by-Step Approach to Using SAS for Factor Analysis and Structural Equation Modeling (2nd Ed.). Cary, NC: SAS Press. ISBN: 978-1-59994-230-8

Ushakov, D.S., Yushkevych, O.O., Ovander, N.L., Tkachuk, H.Yu., \& Vyhovskyi, V.H. (2019). the strategy of thai medical services promotion at foreign markets and development of medical tourism. GeoJournal of Tourism and Geosites, 27(4), 1429-1438.

Tsai, S.P. (2012). Place attachment and tourism marketing: Investigating international tiurists in Singapore. International Journal of Tourism, $139-152$.

Wan, Y.P., \& Sow Hup, J.C. (2013). Factors that affect the levels of tourists' satisfaction and loyalty towards food festivals: a case study of Macau. International Journal of Torism research, 228-239.

Wahyuningtyas N., Tanjung A., Idris I. \& Dewi K. (2019). Disaster mitigation on cultural tourism in lombok, Indonesia. GeoJournal of Tourism and Geosites, 27(4), 1227-1235.

Wang, J. (2017). Economic and cultural impact of tourism marketing. JEL Classification, 53-59.

Westbrook, R.A., \& Oliver, R.I. (n.d.). The dimensionality of consumption emotion patterns and consumer satifaction . Journal of consumer research, 18(1), 84-91.

Xu, B.J., Cao, J., Hansen, T., Yao, D.J., Joswia, N., Wang, G., Wu, M., Wang, H., Zhao, W., Yang, X., \& Liu, J., He. (2009). Black soot and the survival of Tibetan glaciers. Proc. Natl. Acad. Sci., 106, 22114-22118.

Yuan K., Hayashi K., \& Bentler P. (2007). Normal theory likelihood ratio statistic for mean and covariance structure analysis under alternative hypotheses. Journal of Multivariate Analysis, 2007, 9:1262-1282.

*** Customer Satisfaction Theory. (n.d.). Retrieved from Qualtrics: www.qualtrics.com.

*** Descriptive Statistics. (n.d.). Retrieved from Web Center for Social Research Methods: www.socialresearchmethods.net.

*** Defining the term Bantu. (n.d.). Retrieved from South African History: http://www.sahistory.org.za/article/defining-term-bantu.

*** Defining the term 'Bantu'. (2016). Retrieved from SA History Online: http://www.sahistory.org.za/article/defining-term-bantu.

*** Education, T.D. (n.d.). The Impact and Limitations of Colonialism
Article history:
Received: 29.10.2019
Revised: 01.02.2020
Accepted: 25.06.2020
Available online: 10.07.2020 